\title{
POVERTY INCIDENCE IN NEPAL BY CASTE/ ETHNICITY: RECENT LEVELS AND TRENDS
}

\author{
Shambhu Prasad Patel \\ Department of Statistics, T.U., TRM Campus, Birgunj
}

\begin{abstract}
Nepal Living Standard Survey (NLSS) 1995/96 is the first survey in Nepal which provides data on poverty by caste and ethnicity. This paper attempts to trace out the levels and trends of poverty in Nepal by caste and ethnicity on the basis of available data. The findings show wide disparity in poverty between and within the social groups.
\end{abstract}

\section{Keywords}

Caste, dalit, ethnicity, poor, poverty.

\section{Introduction}

The word 'poverty' is derived from the French word 'pauvre' meaning 'poor'. It is a state of lacking material possession of housing or no means to support oneself. Marshall (2005) in dictionary of sociology notes that the concept of 'poverty' has been with us since antiquity, but the meaning has not been constant through out the ages. Friedmann (1992) noted that "moralistic talks" was assigned to the poor states of America. For example, poor has been categorized as

- Blessed Poor : the Bible and other religious doctrines regard that poor are seen as being favoured by the god.

- Destitute: absolute impoverishment.
- $\quad$ Indigent : being needy.

- Working Poor: industrious lives and descerving Poor.

- Popular classes: an expression preferred by the contemporary left in USA.

- Dangerous Classes: Poor as 'dangerous classes' characterized by vice, immoral and potential to rebellion.

In pre-industrialization United Kingdom, the poor laws categorized physically disabled poor and accordingly the provisions of social security were made available to them. In the contemporary world. Poverty is mainly defined from three approaches: income poverty, capability poverty and 
multidimensional view of poverty. Income poverty is based on income or consumption (calorie requirement for being a well nourished). Sen (2000) defined poverty as deprivation in the space of poor into three groups: able-bodied poor, indulgent or beggars and capability. Basic capability is the ability to satisfy the basic crucially important functioning up to certain minimally adequate levels. Functioning range from food, shelter, cloth, good health to more complex sets such as ability to attend a public meeting and ability to participate in public programs. The World Development Report(2001)defines poverty as not only economic concept but also vulnerability, lack of access to various opportunities, insecurity, alienation ,low participation in social and political power.

The poor people in rural areas are characterized by landlessness, too little land, large family, malnutrition, ill-health, illiteracy, high infant mortality rate, low life expectancy at birth, irregular income, isolation due to poor communication and participation and indebtness. Generally most of the rural people have their economy below subsistence level. They have little access to political power, little say in decision making. The five major characteristics of poor people

Table 1: Poverty Incidence by Caste/Ethnicity 1996

\begin{tabular}{|c|c|c|}
\hline Caste/Ethnicity & $\begin{array}{c}\text { Incidence of } \\
\text { Poverty }(\%)\end{array}$ & Traditional occupation \\
\hline 1.Newar & 25 & Commerce/ Industry \\
\hline $\begin{array}{l}\text { 2. i. Bahun (upper) } \\
\text { Ii .Chhetri (upper) } \\
\text { iii. Yadav (middle) } \\
\text { iv Sarki (Dalit) } \\
\text { v Damai (Dalit) } \\
\text { vi Kami (Dalit) }\end{array}$ & $\begin{array}{l}34 \\
50 \\
40 \\
65 \\
67 \\
68\end{array}$ & $\begin{array}{l}\text { Priestly/bureaucracy/politics } \\
\text { Farming/soldiery } \\
\text { Farming /herding } \\
\text { Artisan(leather) } \\
\text { Artisan(music, tailoring) } \\
\text { Artisan(metal) }\end{array}$ \\
\hline 3.Muslim (Minority group) & 38 & Various skills \\
\hline $\begin{array}{l}\text { 4.i. Gurung (Ethnic group) } \\
\text { ii. Tharu " } \\
\text { iii. Rai “ } \\
\text { iv. Magar “ } \\
\text { v. Tamang “ } \\
\text { vi. Limbu “ }\end{array}$ & $\begin{array}{l}45 \\
48 \\
56 \\
58 \\
59 \\
71\end{array}$ & $\begin{array}{l}\text { Farming, foreign army } \\
\text { Farming, foreign army } \\
\text { Farming, foreign army } \\
\text { Farming, foreign army } \\
\text { Farming, foreign army } \\
\text { Farming, foreign army }\end{array}$ \\
\hline 5.Others (other Terai groups) & 37 & Farming, foreign army \\
\hline 6. Nepal & 45 & \\
\hline
\end{tabular}


can be identified as powerlessness, isolation, poverty, physical weakness and vulnerability (Jnawali, 2003).

Global poverty lines are set to (i) proportion of people living to US $\$ 1.25$ dollar per day per person (ii) proportion of people living below US $\$ 2$ dollar. Nepal Living Standard Survey 2010/11 estimated average poverty line at Rs.19,261; the food poverty line at Rs 11,929.and non-food poverty at Rs.7,332. The lack of satisfaction of basic needs is also understood as absolute poverty. It is concerned with the physiological needs of individuals (i.e., food, housing and clothing).

There is extreme paucity of economic data on the basis of caste and ethnicity. This was partly due to lack of caste/ethnic data in population censuses until 1991.This article attempts to present recent levels and trends in poverty in Nepal by caste/ ethnicity by using data of Nepal Living Standard Survey 2010/11.

\section{Past trends in poverty by caste/ ethnicity}

Nepal Living Standard Survey 1995/96 is probably the first earlier survey providing economic data by caste and Pathnicitł 2 : Povertydence by Caste/Ethnicity in Nepal

\begin{tabular}{|c|c|c|c|c|c|}
\hline \multirow[b]{2}{*}{ Caste/ethnicity } & \multirow[b]{2}{*}{$\begin{array}{l}\text { Population } \\
\text { below pov- } \\
\text { erty line ( } \%)\end{array}$} & \multirow[b]{2}{*}{$\begin{array}{c}\text { Poverty } \\
\text { gap(x10o) }\end{array}$} & \multirow[b]{2}{*}{$\begin{array}{c}\text { Poverty gap } \\
\text { Squared } \\
(\mathbf{x 1 0 0}) \\
\end{array}$} & \multicolumn{2}{|c|}{ Distribution of the } \\
\hline & & & & poor & population \\
\hline $\begin{array}{l}\text { 1.Brahman(hill) } \\
\text { 2.Chhetri(hill) } \\
\text { 3.Brahman(Terai) } \\
\text { 4.Middle caste(Terai) } \\
\text { 5.Dalits (hill) } \\
\text { 6.Dalits(Terai) } \\
\text { 7. Newar } \\
\text { 8.Janjati (hill) } \\
\text { 9.Janjati(hill) } \\
\text { 10.Muslim } \\
\text { 11.others }\end{array}$ & $\begin{array}{l}10.34 \\
23.40 \\
18.61 \\
28.69 \\
43.63 \\
38.16 \\
10.25 \\
28.25 \\
25.93 \\
20.18 \\
12.34\end{array}$ & $\begin{array}{l}1.73 \\
5.55 \\
1.75 \\
5.36 \\
10.89 \\
8.09 \\
2.07 \\
6.64 \\
4.48 \\
3.38 \\
3.58\end{array}$ & $\begin{array}{l}0.48 \\
1.86 \\
0.19 \\
1.47 \\
4.22 \\
2.24 \\
0.70 \\
2.49 \\
1.25 \\
0.85 \\
1.13\end{array}$ & $\begin{array}{l}5.2 \\
16.6 \\
0.4 \\
17.6 \\
15.2 \\
6.9 \\
2.5 \\
24.4 \\
7.3 \\
3.5 \\
0.5\end{array}$ & $\begin{array}{l}12.7 \\
17.8 \\
0.5 \\
15.4 \\
8.7 \\
4.6 \\
6.2 \\
21.8 \\
7.1 \\
4.3 \\
0.9\end{array}$ \\
\hline Nepal & 25.16 & 5.43 & 1.81 & 100 & 100 \\
\hline
\end{tabular}

Source : $C B S, 2011$
Table I shows the indicators of poverty incidence for 14 caste/ethnic groups. There is strong evidence of convergence between social hierarchy and poverty level .The analysis of NLSS195/96 data for poverty reveals the level of disparity among social groups. It clearly indicates that the incidence of poverty is least in Newar. While comparing the various castes, the Bahun is the least poor caste with a poverty incidence of 34 percent and the Kami is the poorest caste with poverty incidence of 68 percent. Hill Dalits (Kami, Damai, Sarki) have the highest proportion below poverty line, exceeding 64 percent. It is surprising to note that poverty varies widely within the ethnic groups too. Within ethnic groups, the poverty ranges from 45 percent in Gurung to 71 percent in Limbu, Muslims as well as most Terai castes lie in between high and low poverty incidence.

NLSS 2002/04 found that 31 percent of Nepal's population was below the natural poverty line (CBS.2004, DFID and World Bank, 2005).

\section{Recent levels and trends in poverty}

NLSS 2010/11 provides information on poverty distribution in Nepal by caste/ ethnic groups which is shown in Table 2. 
According to NLSS 2010/11, the poverty incidence for Nepal is 25.16 percent. The poverty rate is much lower in the Newar and the Brahman than other castes/ ethnicities. When comparing all the castes and ethnicities, table 2 indicates that poverty incidence is least in the Newar (10.25\%) followed by the Brahman (10.34\%) and highest in the Dalits of the Hills (43.63\%). Within the Hill castes, poverty ranges from 10.34 percent in the Brahman to 43.63 percent in theDalits. Similarly, within the Terai castes, poverty ranges from as low as 18.61 percent in the Brahman to as high as 38.16 percent in the Dalits. A simple comparison of poverty within the Janajati shows that poverty ranges from 10.34 percent in the Newar to 28.25 percent in the Hills' Janajati. A detail analysis indicates that there is a wide disparity in poverty within each caste/ethnicity.

\section{Conclusion}

The latest estimate of poverty is based on the Nepal Living Standard Survey 201011. Poverty is widespread in Nepal. There is strong convergency between social hierarchy and poverty. Poverty is markedly more pronounced among the Dalits and the Janajati. The causes of poverty are complex and multidimensional. The policy makers should adopt egalitarian policy for eradication of poverty in Nepal.

\section{References}

CBS. (2004). Nepal living standard survey 2003/04. Statistics Report, 1 \& 2, Kathmandu: Central Bureau of Statistics.

CBS. (2011). Poverty in Nepal 2010/11. Kathmandu: Central Bureau of Statistics.

DFID and World Bank (2005). Citizens without rights: Nepal gender and social exclusion assessment. Department for international development. Summary Report. Kathmandu: World Bank.

Friendmann, J. (1992). Empowerment: The politics of alternative development. New York:

Jnawali, D. (2003). Strategies for rural development: A geographical appraisal. Nepal Journal of Development and Rural Studies, 1, 22-34.

Marshal, G. (2005). Dictionary of Sociology. New Delhi: Oxford University Press.

Sen, A. (2000). A decade of human development. Journal of Human Development, $1, \ldots . .$. 